\title{
Perbandingan Kecepatan Dan Ketepatan Menendang Bola Dengan Menggunakan Awalan 1 Meter, 2 Meter, 3 Meter, 4 Meter
}

\author{
Ipung Hari Adi ${ }^{1}$, Moh. Agung Setiabudi ${ }^{2}$, Danang Ari Santoso ${ }^{3}$ \\ 1 Guru PJOK SDN 4 Sukorejo, Kabupaten Banyuwangi \\ 2,3 Prodi Pendidikan Jasmani Kesehatan dan Rekreasi, Universitas PGRI Banyuwangi \\ Email: agungsetiabudi.budi@gmail.com², danangarisantoso@gmail.com³
}

\begin{abstract}
ABSTRAK
Menendang bola merupakan salah satu karakteristik permainan sepak bola yang paling dominan. Tujuan utama menendang bola adalah untuk mengumpan (passing) dan menembak (shooting). Penelitian ini merupakan penelitian deskriptif comparative. Dalam penelitian ini menggunakan purposive sampling karakteristik tertentu yang meliputi sebagai berikut berjenis kelamin laki-laki, telah bergabung di Klub Trias Sukorejo yang berjumlah 20 pemain. Tes yang digunakan dalam penelitian ini adalah tes menembakkan bola ke sasaran. Tes ini bertujuan untuk mengukur ketepatan dan kecepatan menendang bola ke sasaran. Berdasarkan hasil penelitian dapat disimpulkan hal-hal sebagai berikut: Ada perbedaan hasil kecepatan tendangan dalam sepakbola menggunakan awalan 1 meter, 2 meter, 3 meter dan 4 meter. Hal tersebut dapat dilihat dari hasil perbandingan kecepatan laju bola menggunakan awalan 1 meter (1.15), 2 meter (1.07), 3 meter (0.90), dan 4 meter (0.06). Ada perbedaan ketepatan tendangan dalam sepakbola menggunakan awalan 1 meter, 2 meter, 3 meter dan 4 meter. Hal tersebut dilihat dari rata-rata ketepatan menendang yaitu, 1 meter (66.00), 2 meter (64.90), 3 meter (66.65), 4 meter (65.90).
\end{abstract}

Kata kunci: Awalan 1 meter, 2 meter, 3 meter, 4 meter, Kecepatan dan Ketepatan, Menendang Bola

\section{PENDAHULUAN}

Menurut (Suseitom Tarukbua, 2014) bahwa sepakbola merupakan salah satu permainan yang paling banyak digemari banyak orang, baik dari kalangan bawah, menengah maupun kalangan atas. Sepakbola adalah permainan beregu, yang tiap regu terdiri dari sebelas orang pemain salah satunya adalah penjaga gawang, permainan seluruhnya menggunakan kaki kecuali penjaga gawang boleh menggunakan tangan di daerah hukumannya (Sucipto, 2000).Permainan sepakbola merupakan permainan kelompok yang melibatkan banyak unsur, seperti fisik, teknik, taktik, dan mental (Herwin, 2004). Sepakbola adalah permainan dengan cara menendang sebuah bola yang diperebutkan oleh para pemain dari dua kesebelasan yang berbeda dengan bermaksud memasukan bola ke gawang lawan dan mempertahankan gwang sendiri jangan sampai kemasukan bola. (Subagyo, 2010).

Menurut Muhajir (2004) teknik-teknik dasar sepak bola dibedakan menjadi dua yaitu: teknik tanpa bola dan teknik dengan bola. Menendang bola (kicking) dapat dilakukan dengan semua bagian kaki, namun secara teknis agar bola dapat ditendang dengan baik, dapat dilakukan dengan pungung kaki atau kura-kura kaki, sisi kaki bagian dalam, sisi kaki bagian luar, punggung kaki bagian dalam, dan punggung kaki bagian luar (Herwin,2004).

Ketepatan adalah kemampuan seseorang untuk mengendalikan gerakan bebas terhadap sasaran. Mochamad Sajoto (1999) dalam (Muhammad Hilman 2016). Shooting adalah teknik dasar menendang dalam permainan sepakbola dengan cepat, cermat dan tepat pada sasaran untuk membuat gol ke gawang lawan (Sukatamsi, 2007). Jadi shooting adalah menggerakkan salah satu kaki dengan tenaga dan seluruh badan sehingga bola dapat bergerak dengan ketepatan tertentu dan mencapai sasaran yang diinginkan. Menurut Koger (2007) prinsip-prinsip yang harus dilakukan untuk melakukan shooting secara baik adalah sebagai berikut: pandangan pada bola dan 
arah sasaran kemana bola akan ditendang, kaki yang akan menendang, pada saat menendang bola adalah kaki yang memilki tenaga lebih besar, dan sikap badan harus diperhatikan.

Selain ketepatan atau akurasi, teknik menendang bola yang baik juga membutuhkan kecepatan. Kecepatan adalah kemampuan seseorang untuk mngerjakan gerakan keseimbangan dalam bentuk yang sama dalam waktu yang sesingkat singkatnya (Sajoto dalam (Hilman: 2016). Ditinjau dari sistem gerak, kecepatan adalah kemampuan dasar mobilitas sistem saraf pusat dan perangkat otot untuk menampilkan gerakangerakan pada kecepatan tertentu (Fenanlampir dan Faruq dalam Hilman, 2016). Menurut Ismaryati (2008), kecepatan adalah kemampuan bergerak dengan kemungkinan kecepatan tercepat. Kecepatan merupakan gabungan dari tiga elemen, yakni waktu reaksi, frekuensi gerakan per unit waktu dan kecepatan menempuh suatu jarak. Berdasarkan pendapat di atas maka peneliti menyimpulkan bahwa kecepatan adalah merupakan kemampuan seseorang dalam melakukan gerak dalam waktu yang singkat.

\section{METODE}

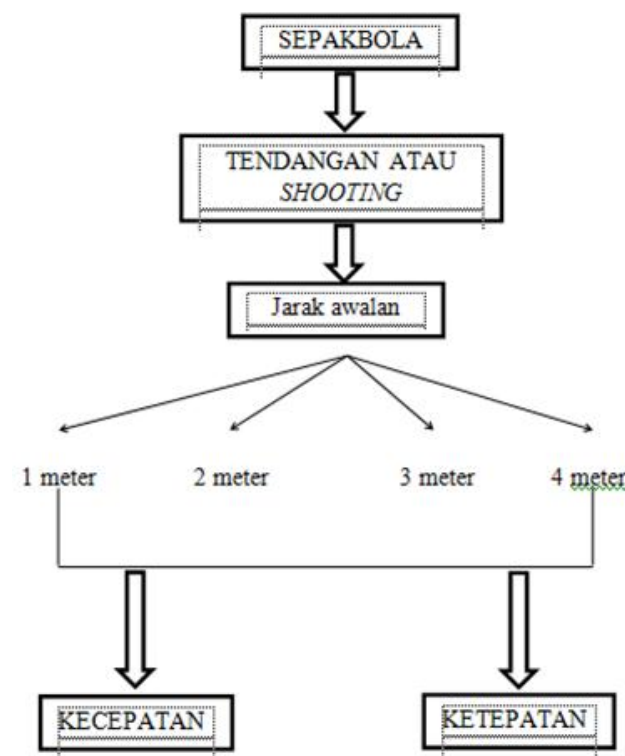

Gambar 1. Kerangka Penelitian

Berdasarkan kerangka penelitian di atas, bahwa sepakbola sangat membutuhkan shooting. Shooting banyak dilakukan pemain depan, tengah, bahkan pemain belakang bila pemain belakang membantu penyerangan. Shooting dapat dilakukan menggunakan awalan maupun tidak menggunakan awalan. Disini penulis meneliti shooting dengan menggunakan awalan $1 \mathrm{~m}, 2 \mathrm{~m}, 3 \mathrm{~m}$, dan $4 \mathrm{~m}$. Shooting dengan menggunakan awalan dilakukan saat pemain depan dilanggar diarea pertahanan lawan dan mendapat tendangan bebas dekat dengan gawang lawan. Disitulah shooting dengan menggunakan awalan dilakukan.

Penelitian ini merupakan penelitian deskriptif comparative. Metode yang digunakan dalam penelitian ini adalah metode survei, sedangkan teknik dan pengumpulan data menggunakan tes dan pengukuran. Dalam penelitian ini menggunakan purposive sampling atau penentuan sampel dengan pertimbangan tertentu atau karakteristik tertentu yang meliputi sebagai berikut berjenis kelamin laki-laki, telah bergabung di Klub Trias Sukorejo yang berjumlah 20 pemain. Tes yang digunakan dalam penelitian ini adalah tes menembakkan bola ke sasaran, (Sukatamsi dalam Huda, 2016). Tes ini bertujuan untuk mengukur ketepatan dan kecepatan menendang bola ke sasaran. Berikut Tes Tendangan dan normanya:

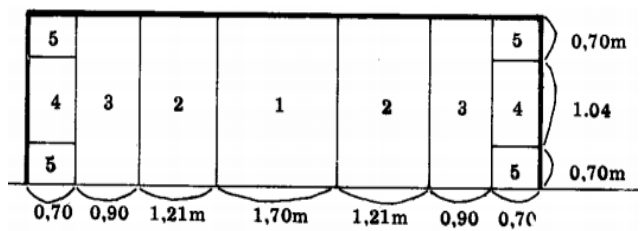

Gambar 2. Dinding Sasaran Tes Tendangan Sumber: (Winarno: 2006)

Tabel 1. Norma Tes Ketepatan dan Kecepatan Sumber: (Winarno, 2006)

\begin{tabular}{|c|l|l|}
\hline NIAI KETERAMPIAN & \multicolumn{2}{|l|}{ GOLONGAN } \\
\hline $61-$ Ke Atas & Baik & (B) \\
\hline $53-60$ & Cukup & $(\mathrm{C})$ \\
\hline $46-52$ & Sedang & $($ S) \\
\hline $37-45$ & Kurang & $(\mathrm{K})$ \\
\hline$\leq-36$ & Kurang Sekali & $(\mathrm{KS})$ \\
\hline
\end{tabular}

HASIL

Hasil penelitian ketepatan tendangan pada table 2 di bawah ini diperoleh melalui 5 kali percobaan,dengan diambil nilai yang terbaik, sehingga dapat dimunculkan pula kategori ketepatan tendangan. 
Tabel 2. Rata-rata Tes Ketepatan Tendangan

\begin{tabular}{|c|c|c|c|c|}
\hline \multirow{3}{*}{ Rata-Rata } & $\begin{array}{c}1 \\
\text { Meter }\end{array}$ & $\begin{array}{c}2 \\
\text { Meter }\end{array}$ & $\begin{array}{c}3 \\
\text { Meter }\end{array}$ & $\begin{array}{c}4 \\
\text { Meter }\end{array}$ \\
\cline { 2 - 5 } & 66.00 & 64.90 & 66.65 & 65.90 \\
\hline Kategori & Baik & Baik & Baik & Baik \\
\hline
\end{tabular}

Dari tabel diatas rata-rata ketepatan tendangan didominasi dengan menggunakan awalan 3 meter hal tersebut disebabkan karena semakin jauh awalan semakin banyak pula ruang gerak untuk membuat dorongan tendangan kearah gawang atau titik sasaran. Seharusnya hasil maksimal terdapat pada awalan 4 meter akan tetapi hasil maksimal diperoleh pada awalan 3 meter hal tersebut dikaranekan pada tumpuan saat akan menendang.

Adapun grafik peningkatan ketepatan tendangan adalah sebagai berikut:

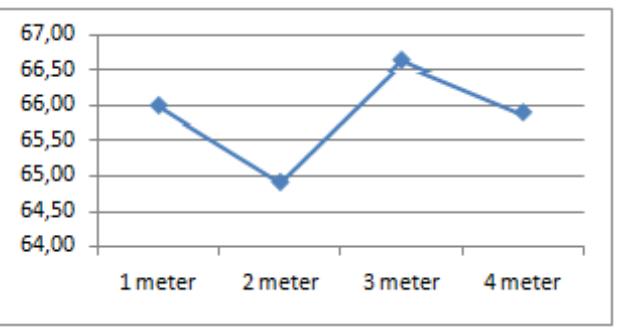

Gambar 2. Grafik Peningkatan Ketepatan Menendang

Hasil perhitungan selanjutnya juga dihitung untuk mendapatkan kecepatan rataratanya. Hasil perhitungan kecepatan bola ditampilkan dalam tabel-tabel berikut ini:

Tabel 3. Rata-rata Kecepatan

\begin{tabular}{|c|c|c|c|c|}
\hline Rata- & 1 Meter & 2 Meter & 3 Meter & 4 Meter \\
\cline { 2 - 5 } Rata & 1.15 & 1.07 & 0.90 & 0.60 \\
\hline Kategori & Sedang & Sedang & Cukup & Baik \\
\hline
\end{tabular}

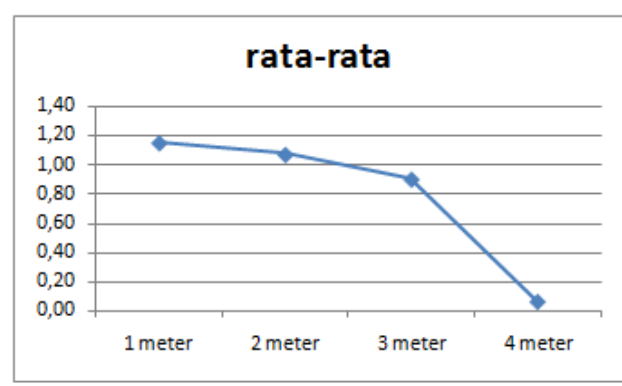

Grafik 2. Grafik Kecepatan Bola Rata-rata

Dari grafik diatas menunjukan bahwa dengan jarak awalan semakin jauh, maka kecepatan tendangan shooting 12 meter semakin meningkat.Hal ini disebabkan karena semakin jauh awalan semakin besar pula ruang gerak untuk membuat dorongan tendangan kearah gawang atau titik sasaran. Grafik juga menunjukkan bahwa kecepatan bola rata-rata maksimum terjadi pada jarak awalan 4 meter yaitu sebesar 20,53 m/dt. Kecepatan bola rata-rata minimum terjadi pada jarak awalan 1 meter yaitu sebesar $10.64 \mathrm{~m} / \mathrm{dt}$.

Dalam kontek fisika gaya semakin kecil, jika masa dan percepatan kecil. Gaya semakin besar jika masa benda dan percepatan besar dengan kata lain dalam penelitian ini dilihat dari jarak penendang, jika jarak awalan penendang semakin jauh maka gaya semakin besar dan kecepatan semakin besar pula. Jika jarak awalan penendang semakin dekat maka gaya semakin kecil dan kecepatan semakin kecil.

\section{PEMBAHASAN}

Dilihat dari hasil penelitian yang dilakukan di Club TRIAS Sukorejo menunjukkan bahwa terdapat perbedaan kecepatan dan ketepatan dengan awalan 1 meter, 2 meter, 3 meter, dan 4 meter. Hal tersebut dapat dilihat dari hasil perbandingan kecepatan laju bola menggunakan awalan 1 meter (1.15), 2 meter (1.07), 3 meter (0.90), dan 4 meter (0.06). Dari hasil rata-rata kecepatan tendangan dapat disimpulkan bahwa semakin jauh jarak awalan maka semakin cepat laju bola sedangkanpada ketepatan jarak awalan 1 meter, 2 meter, 3 meter dan 4 meter, ketepatan yang didapat paling maksimal pada awalan 3 meter. Hal tersebut dilihat dari rata-rata ketepatan menendang yaitu, 1 meter (66.00), 2 meter (64.90), 3 meter (66.65), 4 meter (65.90).

Maka dari itu dapat disimpulkan bahwa jarak awalan sangat berpengaruh terhadap kecepatan menendang terutama laju bola dan ketepatan menendang untuk menentukan target tendangan. Dalam penelitian ini awalan 4 meter tidak mendominasi dalam ketepatan menendang, akan tetapi didominasi awalan 3 meter

\section{KESIMPULAN}

Berdasarkan hasil penelitian diatas dapat disimpulkan hal-hal sebagai berikut: 
1. Ada perbedaan hasil kecepatan tendangan dalam sepakbola menggunakan awalan 1 meter, 2 meter, 3 meter dan 4 meter. Hal tersebut dapat dilihat dari hasil perbandingan kecepatan laju bola menggunakan awalan 1 meter (1.15), 2 meter (1.07), 3 meter (0.90), dan 4 meter (0.06).

2. Ada perbedaan ketepatan tendangan dalam sepakbola menggunakan awalan 1 meter, 2 meter, 3 meter dan 4 meter. Hal tersebut dilihat dari rata-rata ketepatan menendang yaitu, 1 meter (66.00), 2 meter (64.90), 3 meter (66.65), 4 meter (65.90).

\section{DAFTAR PUSTAKA}

Anam, Khoiril. (2013). Pengembangan Latihan Ketepatan Tendangan dalam Sepakbola untuk Anak Kelommpok Umur 13-14 Tahun. Universitas Negeri Semarang.

Arikunto, Suharsimi. (2002). Metode Penelitian. Yogyakarta. Andi Offset.

Arikunto, Suharsimi. (2010). Prosedur Penelitian. Rineka Cipta. Jakarta.

Bompa, Tudor O. Dkk. 2009. Periodization Theory and Methodologi of Training $5^{\text {th }}$ edition. Colorado: Human Kinestics Published.

Herdiansyah, dkk. (2010). Mari Belajar Sepak Bola, Bogor: PT. Regina Eka Utama.

Hilman, Muhammad. (2016). Profil Kondisi Fisik Pemain Sepakbola Perkumpulan Sepakbola Universitas Negeri Yogyakarta. Fakultas IImu Keolahragaan Universitas Negeri Yogyakarta.

Huda, R. Miftakhul. (2013). Perbedaan Tingkat Ketepatan Shooting ke Gawang Antara Pemain Depan, Tengah, dan Belakang Pada Pemain SSB Mas Ku-14 Tahun Yogyakarta. Fakultas IImu Keolahragaan Universitas Negeri Yogyakarta.

Kurniawan, Doni. (2016). Hubungan Antara Kecepatan Lari Dengan Kamampuan Menggiring Bola Sepak Pada Siswa Usia 13-14 Tahun SSB Unibraw 82 Malang. Pendidikan Jasmani dan Kesehatan Universitas Negeri Malang. Muhajir. (2004). Pendidikan Jasmani Teori dan Praktek. Jakarta: Erlangga.
Purnama, Herdi. (2017). Penerapan Media Bola Gantung Untuk Meningkatkan Ketepatan Shooting Menggunakan Punggung Kaki Pada Permainan Sepak Bola. Universitas Pendidikan Indonesia.

Roesdiyanto, dkk. 2008. Dasar-Dasar Ilmiah Kepelatihan Olah Raga. Malang: Laboratorium IImu Keolahragaan Fakultas IImu Keolahragaan Universitas Negeri Malang.

Scheunemann, Timo. 2008. Dasar-dasar Sepakbola Modern untuk Pemain dan Pelatih. Malang: Dioma Publishing.

Sucipto, dkk. (2000). Sepakbola.Jakarta: Direktoral Jenderal Pendidikan Dasar dan Menengah.

Sugiyono. (2006). Statistika untuk Penelitian. Bandung: CVF Alfabeta

Sukatamsi. (2007). Permainan Bola Besar Sepakbola.Universitas Terbuka Jakarta.

Tarukbua, M. Suseitom. (2014). Kontribusi Panjang Tungkai Terhadap Jauhnya Tendangan Dalam Permainan Sepakbola Pada Siswa SD Inpres Kapiroe Kecamatan Palolo Kabupaten Sigi. Pendidikan Jasmani, Kesehatan dan Rekreasi FKIP Universitas Tadulako Kampus Bumi Tadulako Tondo. Palu Sulawesi Tengah.

Wahyuno, Dani. (2014). Studi Kondisi Fisik Atlet Sepak Bola Persatuan Sepak Bola Fakultas Keguruan dan IImu Pendidikan. Universitas Bengkulu.

Wibowo, Nuryanto. (2013). Pengaruh Latihan Ball Feeling Terhadap Kemampuan Dribbling Pada Siswa Peserta Sekolah Sepak Bola (SSB) Melati Muda (MM) Bantul 13-15 Tahun.Universitas Negeri Yogyakarta.

Winarno, M.E. (2006). Evaluasi Dalam Pendidikan Jasmani Dan Keolaragaan. Center for Human Capacity Development 2004. Jakarta. 